\title{
Linguistic repertoires and textual genres in academic writing
}

\begin{abstract}
This essay provides a reflection on the impact of the variety of languages, knowledge and practices in school contexts. The discussion includes textual genres in different writing modalities in academic communicative interactions and sources of multimedia textuality. Linguistic academic performances incorporate native, foreign and second languages. In this complex textuality context, linguistic repertoires and textual genres involve an integral and transversal writing approach. Multiple language manifestations and modalities shape linguistic and disciplinary knowledge within the framework of academic socialization. Language interactions are contextualized in a complex print, digital, multimedia and online communication in academic literacies in school experiences.
\end{abstract}

Keywords: linguistic repertories, textual genres, academic communication, languages, knowledge
Volume 3 Issue 5 - 2019

\author{
Ernesto Hernández Rodríguez \\ Tutor and Researcher, National Preparatory School, National \\ Autonomous University of Mexico, Mexico
}

\begin{abstract}
Correspondence: Ernesto Hernández Rodríguez, Tutor and Researcher, National Preparatory School, National Autonomous University of Mexico, Mexico, Email ernestotem@live.com.mx
\end{abstract}

Received: July 22, 2019 | Published: September 05, 2019

\section{Introduction}

Nowadays, we are in a stage of complex evolution of the variability of writing practices and resources in different media, for example, handwriting, the displaced typewriter by the computer keyboard, printed and electronic texts, multimedia resources and many textual possibilities on internet. This multiplicity of writing possibilities appears in different modalities and styles in everyday life and in school activities.

In academic situations, we are involved in the context of linguistic repertoires, understood as the variety of language, knowledge and practices that people experience in certain interactions and communicative functions, as well as textual genres in a variety of modalities. Likewise, the complex communicative interactions and the numerous sources of textuality evidence the difficulties to characterize linguistic performances in school and academic environments. Students need to develop written interaction in native, foreign and second languages and in certain bilingual and multilingual situations. The efforts to study communicative performances of students have emphasized the characterization of linguistic repertoires, ${ }^{1}$ discursive resources, textual genres, ${ }^{2,3}$ bilingual and multilingual communities, ${ }^{4-6}$ types of printed and online writing, as well as written interaction in school environments.

The multiplicity of textual practices imposes the need for revision and renewal in the proposals of educational plans, programs and approaches. This conception responds to knowledge evolution, writing performances and resources in the printed, multimedia and internet options. The possible changes are not only limited to the incorporation of many skills in the handling of information, of diverse resources and formats in textual typologies. The proposal is that academic communication contemplates the knowledge and language development of writing practices. In this way, students may achieve the enrichment of linguistic repertoires and textual genres, as the means of learning in a variety of disciplinary subjects. This perspective implies writing in different modalities to favor the critical handling of contents, academic interaction and meaningful communication. The challenge is that the curriculum, plans and study programs in schools incorporate these considerations to respond to the knowledge and learning needs of writing in academic experiences.

\section{Linguistic characterization of performances}

The variability and complexity of linguistic practices and writing resources in the contexts of the current daily and school environment are manifested in the difficulties and controversies to study students' written performance. The proposal of linguistic repertoires, ${ }^{1,7}$ incorporates language knowledge, varieties, practices, trajectories, resource collections, strategies and performances. These aspects develop according to certain codes and communicative situations "in current phenomena such as increased mobility, migration, or participation in transnational networks of communication". " In this perspective, interactions include not only global worldwide languages for international and business interaction, but also indigenous languages and plurilingual contexts. ${ }^{8}$ Thus, the main objective in the repertoires approach is the characterization of linguistic knowledge, performances, context, cultural and ethnic manifestations in multimodal interaction as a result of complex and dynamic communication.

In school environments, a student may have different knowledge and developments of certain language skills. Specific linguistic performances respond to the needs of communication and academic socialization, interaction, practices, styles, disciplinary traditions, resource management and textuality manifestations. Each student may exhibit personal linguistic trajectories with multimodal possibilities and levels of competence and performance in written, oral, listening, reading and oral skills, for example, in first, second, foreign, indigenous and historical languages. The trajectories of textual experiences are different for each student according to personal linguistic characterization and school experiences in everyday life. 
In written tasks, students can use multiple textual knowledge and resources for revision, editing and consultation of handwritten, printed and online sources, translators and intertextuality in hyperlinks. ${ }^{9,10}$ In each activity, students manage strategies related to textual manifestations and communicative functions, for example, writing to take notes and systematizing information in worksheets on paper and electronic devices. ${ }^{11}$ Likewise, online written communication, in forums, blogs, interactive platforms, social networks and academic repositories, requires the development of textual conceptions and performances in each written situation. ${ }^{12-15}$

The characterization of a certain textual genre is complex and is associated to diverse criteria, agreements, traditions and preferences in different times and environments. Bajtín, ${ }^{2}$ Van Dijk ${ }^{3}$ and Adam $^{16}$ address the problem of identifying and classifying textual genres and discursive resources, due to their permanent evolution in each historical and contextual situation. In school writing, we find a variety of considerations and agreements on the formal and thematic characteristics of a given gender, within the framework of academic socialization contexts. ${ }^{17}$ For example, Hernández Rodríguez ${ }^{18}$ contemplates that there are different criteria to write essays in science, humanities, philosophy and literary traditions. Thus, in order to write in many subjects, students have to adjust their textual and knowledge repertoires in the style of each teacher or expectations in specific academic communities. The creative and versatile management of texts, in the functions and contexts of school communication, allows the enrichment of linguistic knowledge and resources in different academic socialization traditions. It is fundamental that writing experiences in academic and scholar contexts promote constant and critical development of text genres, experiences and strategies to interact according to multiple performance expectations in school communication.

The characterization of students' academic writing in terms of the textuality standards, proposed by De Beugrande \& Dressler, ${ }^{19}$ allows us to contemplate the considerations and expectations that authors and readers conceive about the characteristics of a written task. These performance criteria involve intentionality to adequately fulfill the communicative purpose, in this case, in school environment. Furthermore, we apply the tolerance principle to try to comprehend texts with problems, for example, in cohesion and coherence. In addition, these researchers propose that in feedback and self-regulated writing we take into account the characteristics and expectations of a text through the following textuality standards: cohesion, coherence, intentionality, informativity, situationality, acceptability and intertextuality. We can consider these criteria as the basic considerations and expectations related to writing practices experienced in multiple academic socialization contexts. Also, in a textuality perspective, intentionality involves interpretations and expectations related to interlocutors. ${ }^{20,21}$

The coexistence of native and foreign languages in the school environment is a fundamental issue in nowadays academic interaction. The presence of languages for spreading knowledge and science, mainly in English, in school interaction and in many other everyday situations is evident for specific purposes. Therefore, the characterization of native, second and foreign languages in interactive situations, domains, contexts, and functions involves contemplating levels of incipient, functional and coordinated bilinguisms and multilinguisms in the perspectives of Manrique Castañeda, ${ }^{4}$ Romaine ${ }^{6}$ and Cifuentes. ${ }^{5}$ These approaches consider that a language appears in certain domains, or situational and contextual communicative functions, according to a suitable determined level of performance that is useful for a specific interactive purpose. For example, in a specific bilingual characterization, we can consider those who can only read in a foreign language, but do not communicate orally and vice versa, or those who develop foreign language skills in a family or business environment, but not in school or academic tasks. ${ }^{6}$ The goal is to help students to become aware of their linguistic repertoires to develop multiple language domains for communication. In this way, they may interact in a variety of contexts and decide to improve their knowledge and performance in certain languages in different levels and skills.

\section{Strengthening academic writing}

A general characterization of linguistic performances in academic and school contexts implies the need to conceive writing practices as objects of learning in multiple disciplinary contents in all school subjects. In this way, we can improve writing experiences in different text genres with purposes to communicate and disseminate knowledge. The challenge is to achieve, for example, that school programs and curricula designs explicitly state discursive resources, textual genres characteristics and considerations of academic socialization and written literacies in a variety of linguistic communicative domains. Thus, students may be able to appreciate the distinction, for example, of descriptive, expository and argumentative texts, and the language styles adopted by each academic community, corresponding to disciplines in specific contexts. This proposal implies that teachers reflect on their conceptions related to textual genres and their expectations regarding students' performances in written tasks.

The coexistence of linguistic repertoires and varieties of textual genres in the student population should be conceived as a situation that we can take advantage of in school writing practices. But we must not consider that simple handling of multiple decontextualized linguistic collections and performances in printed, multimedia and online modes necessarily translates into better learning in all disciplinary subjects. The proposal to enrich linguistic repertoires and modalities requires incorporating academic writing into the perspectives of academic socialization and literacies through an integral and transversal development of writing to interrelate linguistic and disciplinary knowledge.

In order to write comments, reviews, summaries, monographs and essays, for example, in the native and foreign languages, students need to experience the uses and functions of each textual genre in specific academic domains, with appropriate feedback for revision and editing..$^{22,23}$ For this purpose, it is useful to incorporate sources to encourage the development of repertoires in linguistic knowledge and strategies for learning purposes. In this way, we can experience, for example, with the grammar spelling correctors in word processors, online information retrievers, translators, multimedia and interactive resources, hyperlinks, and the recognition of formats, genres and textual styles. These practices should be experienced with academic criteria, contextual and cultural socialization of writing in disciplinary communities and traditions corresponding to each subject.

In the coexistence of native, foreign and second languages in academic contexts, it is fundamental that learning experiences contemplate the reflection and interrelation of knowledge in languages involved in written practices. Eventually, students have to solve difficulties in translation and bilingual writing of summaries, biodata 
or certain passages of school texts. Given these needs, the proposals of Nida, ${ }^{24}$ Bassnet, ${ }^{25}$ Pegenaute, ${ }^{26}$ Nord $^{27}$ and $\mathrm{Eco}^{28}$ contemplate that translation implies rewriting, recomposition or improvement of the original text whenever it exhibits writing problems. These practices favor the metalinguistic reflections on the differences and similarities of languages in bilingual writing when students translate their texts. In this line of research, Popovič ${ }^{29}$ Cocco $^{30}$ Grutman \& Van Bolderen ${ }^{31}$ and Jung ${ }^{32}$ characterize linguistic performances in certain contexts and communicative functions. In multilingual contexts, Francis \& Hamel $^{33}$ and Francis ${ }^{34}$ study bilingual indigenous students' written performance in Spanish, Otomí and Náhuatl in the Mexican states of Hidalgo, Tlaxcala and Puebla. Spicer-Escalante considers students bilingual, Spanish-English, writing in The United States. Hernández Rodrígue $^{35}$ provides research about linguistic performances, difficulties and reflexivity in university academic writing in Spanish in Oaxaca, Mexico.

The critical teaching conceptions of integrated grammar, semantic, pragmatic and cultural elements favor language learning. Thus, it is necessary to eliminate radical approaches that consider that teaching grammar impairs the communicative and practical development of native and foreign languages. On the contrary, it is fundamental to contemplate a critical perspective in grammar teaching with application in improving the performance of linguistic skills. Currently, we find a multiplicity of printed and online tools to strengthen grammar knowledge, based on the development of written expression. Likewise, we require a significant characterization of the types or levels of incipient, partial and functional bilingualisms to assess communication in a given linguistic ability, in this case, writing in different modalities in terms of communicative repertoires. Those who can read or write in a certain language, despite not having other skills developed, have the possibility to use this knowledge as a communicative learning tool. ${ }^{6}$ It is not necessary to achieve full development levels of performance in all linguistic skills as a goal of academic communication. Indeed, it is practically impossible for an individual to develop a full integral development of all the elements and functions of a language. In fact, we permanently continue the learning process of languages, as enrichment of our linguistic repertoires in multilingual interactions.

In addition to the considerations on the coexistence of linguistic repertoires, academic communication needs to incorporate textual genres, criteria for characterizing the management of multiple languages, an interactive approach and the construction of identity through school experiences in many written communication modalities. Students assume behaviors and attitudes in order to adapt to the characteristics and situations of academic communication. Interaction and feedback become important elements of follow-up, accompaniment and motivation for writing. In review and editing, students assume expectations related to interaction and reception of their performances in different subjects in the face-to-face and distance modalities. Ivanic ${ }^{36}$ considers that students experience certain attitudes towards interaction, feedback and suggestions about their texts in academic communication.

In multimedia written communication, students create links that develop social interaction and identity. ${ }^{37}$ In this way, they are able to experience interactivity and create intertextuality, ${ }^{38}$ related to multiple textual sources. Therefore, academic writing experiences in multimedia possibilities should encourage students to be open to criticism and reflection on their written performances. This objective can be achieved in a gradual process of interactive learning when writing is conceived as an object of learning for communication and knowledge construction in linguistic school experiences. ${ }^{39,40}$

Students learn to develop written interaction options when they participate in different communication modalities imposed by school environments and dynamics. Thus, they learn to recognize and communicate in multiple languages and cultural contexts, textual genres, lexicon selections, and modalities in print, digital, multimedia and online texts. The management of textual resources appears in different expressions, for example, in the writing of comments, notes, digital presentations, forums, chats and social networks on the internet, as proposed by Whitman. ${ }^{41}$ Students learn to self-regulate their textual resources by recognizing genres, writing supports, contextual and cultural aspects, and by taking into account expectations of their interlocutors about the reception of their writings in school environments.

\section{Final considerations}

Given the coexistence of students' multiple linguistic interactions, the evolution of academic genres and efforts to characterize performance in native, second and foreign languages and the challenge in academic communication lies in proposing transversal and integral practices to enrich linguistic repertoires in multiple subjects. This effort involves considering that writing experiences constitute fundamental tools in shaping knowledge and everyday school communication. It is essential to eliminate decontextualized learning skills, the lack of language and knowledge interrelation, the ideas that writing is only learned in language classes and the conceptions that teaching grammar and written translations impair communicative interaction and language learning.

The coexistence and evolution of linguistic repertoires can be used to promote learning. We can develop them in different situations and specific contexts, as a result of our personal trajectories. In this sense, academic communication must provide significant experiences to integrate teaching and student communities that support the development of knowledge in classrooms and in other forums that enable writing. Therefore, it is not enough to promote decontextualized management of multiple linguistic resources in academic writing. We need to contemplate that new information and communication technologies in multiple linguistic interactions and contexts are useful to develop textual knowledge in different subjects.

\section{Acknowledgments}

None.

\section{Conflicts of interest}

The authors declare that there are no conflicts of interest.

\section{Funding}

None.

\section{References}

1. Blommaert J, Backus A. Superdiverse repertories and the individual. In Saint-Georges, Ingrid de \& Weber, Jean-Jacques, Multimodality and multilingualism: Current challenges for educational studies. Rotterdam: Sense Publishers. 2013;11-32. 
2. Bajtín M. Aesthetics of verbal creation. México: Siglo XXI. 1982.

3. Van Dijk TA. The science of the text. México: Paidós. 1983.

4. Manrique Castañeda L. Cultural Atlas of Mexico: Linguistics. México: SEP-INAH-Planeta. 1988.

5. Cifuentes B. Lyrics about voices: Multilingualism throughout history. México: Ciesas-INI. 1998.

6. Romaine S. Bilingualism. Cambridge USA: Blackwell. 1995.

7. Busch B. Expanding the Notion of the Linguistic Repertoire: On the Concept of Spracherleben-The Lived Experience of Language. Applied Linguistics. 2017;38(3):340-358.

8. Zanasi L, Platzgummer V. Linguistic repertoires in multilingual contexts In: Hepp M, Nied Curcio M, editors. Educazione plurilingue: ricerca, didattica e politiche linguistiche, Studi Germanici, Roma. 2017;51-64.

9. Fredholm K. Online translation use in Spanish as a foreign language essay writing: effects on fluency, complexity and accuracy. Revista Nebrija de lingüística aplicada. 2012;8:1-18.

10. Flores-Carrasco PG, Díaz-Mujica A, Lagos-Herrera IE. Comprensión de textos en soporte digital e impreso y autorregulación del aprendizaje en grupos universitarios de estudiantes de educación. Revista electrónica Educare. 2017;21(1):1-17.

11. Stacy EM, Cain J. Note-taking and handouts in the digital age. American Journal of Pharmaceutical Education. 2015;79(7):107.

12. Blikstad-Balas M. Digital Literacy in Upper Secondary School - What do students use their laptops for during teacher instruction? Nordic journal of digital literacy. 2015;10:9.

13. Hernández Rodríguez E. Overview of literacy and academic writing in higher education. In: Héctor Muñoz Cruz, Editor. Textuality and foreign language in the academic development of bilingual students in higher education. México: UAM Iztapalapa. Conacyt. 2013;17-48.

14. Cordón JA. Reading in the digital environment: new materialities and discursive practices. Revista chilena de literatura. 2016;94:15-38.

15. López Flamarique M. Search, evaluate and select digital information: a didactic experience in secondary education. Tesis doctoral. Mondragon University. 2017

16. Adam JM. Textual linguistics. From genres of speech to texts. A methodical introduction to the textual analysis of speeches. Paris: Nathan. 2004.

17. Street BV. The future of social literacies. In: Baynham M, Prinsloo M, Editors. The future of literacy studies. Hampshire: Macmilan. 2009;21-37.

18. Hernández Rodríguez E. Performance and intentionality when considering expectations, agreements and practices to write essays in a high school Mexican context. Open Access Journal of Science. 2019;3(1):4-11.

19. Beugrande R, Dressler W. Introduction to Text Linguistics. Barcelona: Ariel-Lingüística. 1997.

20. Paredes M. Theories of Intentionality. Madrid: Síntesis. 2007.

21. Beuchot M. Essential elements of an analog hermeneutic. Diánoia. 2015;60(74):127-145.

22. Fabre-Cols C. Rewrite in School and College: From Analysis of Drafts to Accompanied Writing. Issy-les-Moulineaux: ESF éditeur. 2002;29-30.

23. Macklin T. Compassionate Writing Response: Using Dialogic Feedback to Encourage Student Voice in the First-Year Composition Classroom Journal of Response to Writing. 2016;2(2):88-105.

24. Nida E. Contexts in translating. Ámsterdam/Philadelphia: John Benjamins Publishing Company. 2001.

25. Bassnett S. Writing and translating. In: Bassnett S, Bush P, Editors. The translator as writer. London: Continuum. 2006;172-182.

26. Pegenaute L. Translation as a teaching tool. Contextos. 1996;14(27-28):107-125.

27. Nord Ch. Text analysis in translation: Theory, methodology and didactic application of a model for translation-oriented text analysis. Amsterdam: Rodopi. 1991.

28. Eco U. Say almost the same: Translation experiences. Barcelona: Lumen. 2008.

29. Popovič A. Dictionary for the Analysis of Literary Translation. Edmonton: Department of Comparative Literature University of Alberta. 1976.

30. Cocco S. Lost in Translation. Texts and cultures in the mirror. AnnalSS 2009;6:103-118.

31. Grutman R, Van Bolderen T. Self translation. In: Berman S, Porter C, Editors. A companion to translation studies. West Sussex: WileyBlackwell. 2014;323-332.

32. Jung V. English-German self translation of academic texts and its relevance for translation theory and practice. Oxford: Peter Lang International Academic Publishers. 2002.

33. Francis N, Rainer EH. Writing in two languages: writing and narrative in three bilingual schools of the Mezquital Valley. In Revista Latinoamericana de Estudios Educativos. 1992;22(4):11-35.

34. Francis N. The bilingual writing workshop on documentation and rescue of indigenous languages: a space for theoretical reflection. Lenguas en Contexto. 2011;7:3-10.

35. Hernández Rodríguez E, Reyes Galicia E. Interactivity and digital textuality to develop multimedia materials with songs for learning the foreign language in the high school media library. Re Lingüistica aplicada. 2015;11(17):7.

36. Ivanič R. Writing and identity: The discoursal construction of identity in academic writing. Philadelphia: John Benjamins Publishing Company. 1988.

37. Serrano-Puche J. Connected lives: digital technology, social interaction and identity. Historia y comunicación social. 2013;18:353-364.

38. Cerić V. Digital text: interactivity and intertextuality. Online Journal of art and design. 2013;1(1):17-31.

39. Álvarez G, González A, Bassa L. Apuntes para pensar the propology of tecnologias in the teaching of the reading and the writing. In: Cabello R, López A. Editors. Contributions to the study of technology appropriation processes. Buenos Aires: Ediciones del Gato Gray \& Red from Researchers on Technology Appropriation. 2017;1-245.

40. Álvarez Otero B. Concepts about learning and teaching through writing in natural science class. PhD thesis Autonomous University of Barcelona. 2018 .

41. Whitman L. The Effectiveness of interactivity in computer-based instructional diagrams. In: Jacko JA, Editors. Human Computer Interaction. 2009;2:889-908. 